\title{
Neonatal Type I diabetes associated with maternal echovirus 6 infection: a case report
}

\author{
T. Otonkoski ${ }^{1}$, M. Roivainen ${ }^{2}$, O. Vaarala ${ }^{2}$, B. Dinesen ${ }^{3}$, J. A.Leipälä ${ }^{1}$, T.Hovi ${ }^{2}$, M.Knip ${ }^{4}$ \\ ${ }^{1}$ Hospital for Children and Adolescents and Haartman Institute, Transplantation Laboratory, University of Helsinki, Helsinki, \\ Finland \\ ${ }^{2}$ National Public Health Institute, Helsinki, Finland \\ ${ }^{3}$ Steno Diabetes Center, Gentofte, Denmark \\ ${ }^{4}$ Medical School, University of Tampere and Department of Paediatrics, Tampere University Hospital, Tampere, Finland
}

\section{Abstract}

Aims/hypothesis. Neonatal diabetes mellitus is rare, and it has not been associated with beta-cell autoimmunity. Enteroviral infections during pregnancy have been implicated as a risk factor for the later development of Type I (insulin-dependent) diabetes mellitus. We now report of a baby girl who was born severely growth-retarded with neonatal insulin-deficient diabetes, and look for evidence of intrauterine enteroviral infections and beta-cell targeted autoimmunity.

Methods. Diabetes-associated autoimmunity was studied by measurement of several types of islet cell reactive autoantibodies. The infant's T-cell responses to insulin and enterovirus antigens were recorded and enterovirus antibodies were measured both from the mother and the child.

Results. Several types of diabetes-associated autoantibodies were detected postnatally, including insulin autoantibodies, conventional islet cell autoantibodies and glutamic acid decarboxylase antibodies, whereas no autoantibodies were observed in the mother. The infant's T-cells showed reactivity to insulin and purified enterovirus particles. Based on serological studies, the pathogenetic process could have been triggered by an echovirus 6 infection during pregnancy. The patient's diabetes has been permanent, although there were signs of endogenous insulin production for several months. Exocrine pancreatic insufficiency was diagnosed at the age of 1 year.

Conclusion/interpretation. These observations suggests that enteroviral infections may induce beta-cell autoimmunity even in utero. [Diabetologia (2000) 43: $1235-1238$ ]

Keywords Neonatal diabetes mellitus, autoantibodies, enteroviruses, fetal growth retardation.
Autoantibodies associated with the pancreatic beta cell have been detected at increased frequency in the cord blood of babies who later developed diabetes, suggesting that pathogenesis of diabetes could be initiated in utero [1]. Clinical Type I (insulin-depen-

Received: 11 April and in revised form: 8 June 2000

Corresponding author: T. Otonkoski, MD, PhD, Haartman Institute, Transplantation Laboratory, PO Box 21 (Haartmaninkatu 3), 00014 University of Helsinki, Helsinki, Finland Abbreviations: IAA, insulin autoantibodies; ICA, islet cell autoantibodies; GADA, glutamic acid decarboxylase autoantibodies; IA-2A, tyrosine phosphatase IA-2 autoantibodies; RU, reference units; CBV-4, coxsackievirus B4; SI, stimulation index; PHA, phytohaemagglutinin. dent) diabetes mellitus is, however, rarely diagnosed before the age of 2 years and it has not been observed to present before the age of 3 months.

Neonatal diabetes is rare, estimated incidence being 1:400 000 live births [2]. Its cause is not known in most cases. Transient neonatal diabetes has been associated with paternal uniparental isodisomy of chromosome 6 [3]. Homozygotic mutation of the $p d x-1$ gene has been shown to result in congenital diabetes with pancreatic agenesis [4]. There have been no reports of islet-cell autoimmunity associated with neonatal diabetes [2]. We now report of an infant who developed apparent autoimmune Type I diabetes in utero. 


\section{Subjects and methods}

Endogenous insulin production and HLA typing. The concentration of total proinsulin was measured by ELISA with a broad specificity including all four proinsulin conversion intermediates $(65-99 \%)$ together with intact proinsulin $(100 \%)$. We measured $\mathrm{C}$ peptide using time-resolved immunofluorometry (AutoDELFIA, Wallac, Turku, Finland). The limit of detection was $5 \mathrm{pmol} / \mathrm{l}$. We defined HLA-DQB1 alleles by a previously described method based on time-resolved fluorescence. Four sequence-specific oligonucleotide probes were used to identify the following DQB1 alleles known to be associated with either susceptibility to or protection against Type I diabetes in the Finnish population: DQB1*0302, DQB1*02, DQB1*0602 or 0603 , and DQB1*0301.

Diabetes-associated autoimmunity. Antibodies against islet cells (ICA), glutamic acid decarboxylase (GADA) and the protein tyrosine phosphatase-related IA-2 molecule (IA-2A) were analysed as described previously [5]. Insulin autoantibody (IAA) concentrations were measured with a recently established microassay [6]. The detection limit of the ICA assay was 2.5 Juvenile Diabetes Foundation (JDF) units. The cutoff limits for positivity for IAA, GADA and IA-2A were set at the $99^{\text {th }}$ centile [(1.56 reference units (RU) for IAA, 5.35 RU for GADA and $0.43 \mathrm{RU}$ for IA-2A, respectively)] in more than 370 non-diabetic Finnish children. We studied Tcell responses by a proliferation test of peripheral blood mononuclear cells. Human and bovine insulin (Sigma, St Louis, Mo., USA) at the concentration of $100 \mu \mathrm{g} / \mathrm{ml}, 10 \mu \mathrm{g} / \mathrm{ml}$ of GAD produced in the baculovirus expression system, $1 \mu \mathrm{g} / \mathrm{ml}$ of purified coxsackievirus B4 (CBV-4), $20 \mu \mathrm{g} / \mathrm{ml}$ of tetanus toxoid and $5 \mu \mathrm{g} / \mathrm{ml}$ of phytohaemagglutinin (PHA) were used as antigens. The results are expressed as stimulation indexes (SI). As an enterovirus antigen we used only CBV-4 because it has been shown that human T-cell epitopes are cross-reactive among different enteroviruses [7].

Enterovirus antibodies. We analysed IgM class antibodies by using a heavy-chain-capture RIA against a panel of enterovirus antigens including procapsid antigens of CBV-5, echo-1 and CAV-9 as described earlier [8]. Enterovirus group-specific IgG class antibodies were analysed using an EIA method against a synthetic peptide antigen (amino acid sequence KEVPALTAVETGAT-C) derived from an immunodominant region of capsid protein VP1, known to be a common antigenic determinant for enteroviruses. The peptide EIA has turned out to be a specific test for detection of enterovirus infections [8].

Antibody titres against specific enteroviruses were measured using a plaque assay [9]. Serial fourfold dilutions of sera to be tested were mixed with an equal volume of pretitrated virus (about 100 plaque-forming units in $6 \mu \mathrm{l}$ ). The mixture was incubated for 1 hour at $36^{\circ} \mathrm{C}$ and overnight at room temperature. Virus propagation medium $(110 \mu \mathrm{l})$ was added and the amount of virus still alive after neutralization was quantified by plaque assay. Confluent monolayers of GMK cells (A-549 cells for HPEV-1) were grown in six-well plates. Preneutralized virus samples were put onto the cell monolayers in volumes of $50 \mu \mathrm{l}$. After $30 \mathrm{~min}$ incubation at $36^{\circ} \mathrm{C}, 2 \mathrm{ml}$ of plaqueing overlay $(0.5 \%$ carboxymethyl cellulose in the Eagle's minimal essential medium supplemented with $1 \%$ fetal calf serum,

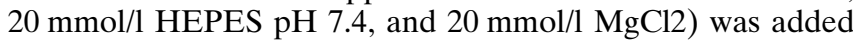
and infected cells were incubated for $46 \mathrm{~h}$ at $36^{\circ} \mathrm{C}$. The amount of adsorbed infectious virus was scored by counting the plaques after crystal violet staining. Reciprocal of the last dilution of serum able to block virus infectivity by $85 \%$ was taken as the titre of the serum specimen. The virus strains (CAV9, CBV-1, CBV-2, CBV-3, CBV-4, CBV-5, CBV-6, EV-1, EV-7, EV-11, HPEV-1) used in this study comprised reference strains of enteroviruses that were originally obtained from the American Type Culture Collection.

\section{Results}

The baby was born from the second pregnancy of a 30 -year-old mother. The mother suffered from an acute gastroenteritis at the $14^{\text {th }}$ week of gestation. Fetal growth retardation was observed ultrasonically in week 34. A female infant with a birth weight of 1380 g [-5 Standard deviation score (SDS)], length $40.5 \mathrm{~cm}(-5$ SDS $)$ and head circumference $30.5 \mathrm{~cm}$ (-2.5 SDS) was delivered by Caesarean section at 37.4 weeks. Persistent hyperglycaemia and ketosis were noted from the first hours after birth, necessitating insulin treatment which normalized the infant's metabolic status. She was treated with intravenous insulin infusion until the age of 40 days when continuous subcutaneous insulin infusion was commenced, using 1:10 diluted insulin in a portable pump (HTron V100, Disetronic, Minneapolis, Minn., USA). The insulin requirement was initially $0.5-0.7$ $\mathrm{IU} \cdot \mathrm{kg}^{-1} \cdot \mathrm{day}^{-1}$ for the first 2 months and decreased thereafter to approximately $0.25 \mathrm{IU} \cdot \mathrm{kg}^{-1} \cdot \mathrm{day}^{-1}$. At this time, the concentration of serum proinsulin was $10.0 \mathrm{pmol} / \mathrm{l}$ and $\mathrm{C}$ peptide $34 \mathrm{pmol} / \mathrm{l}$, whereas that of blood glucose was $8.1 \mathrm{mmol} / \mathrm{l}$, indicating low endogenous insulin production. After the age of 8 months, the insulin requirement increased to the expected concentration of $0.5-0.6 \mathrm{IU} \cdot \mathrm{kg}^{-1} \cdot \mathrm{day}^{-1}$ and C peptide was no longer detectable. There have been no episodes of serious hypoglycaemia and the metabolic control has remained adequate $(\mathrm{HbA} 1 \mathrm{c}<8.7 \%)$. Symptoms of exocrine pancreatic insufficiency (poor weight gain, episodes of diarrhoea) developed after 8 months of age. Low fecal elastase concentration was detected and replacement therapy with oral pancreatic enzymes commenced. At the age of 1 year, an abdominal magnetic resonance imaging (MRI) showed a hypoplastic pancreas with pancreatic tissue clearly identifiable only in the area of the pancreatic head. Cystic fibrosis was excluded by a normal sweat chloride concentration.

The infant's serum contained high concentrations of insulin autoantibodies (IAA), even in the sample taken before the onset of insulin treatment (Table 1). Conventional islet-cell antibodies (ICA) were also constantly present. Glutamic acid decarboxylase antibodies (GADA) turned positive soon after birth and have increased to a high level. Throughout follow-up IA-1 antibodies have remained negative. The infant was found to carry the HLA-DQB1*0302 allele which is associated with an increased risk for Type I diabetes but not the protective allele DQB1*0602. 
Table 1. Islet cell-associated antibody concentrations measured in serum samples

\begin{tabular}{lllllll}
\hline & \multicolumn{2}{l}{ Age } & & \\
\cline { 2 - 5 } & 1 day & 4 days & 2 months & 6 months & 12 months \\
\hline ICA (JDFU) ${ }^{\mathrm{a}}$ & 15 & nd & 28 & 8 & 8 & 0 \\
IAA (RU) & 2823 & 2359 & 3224 & 1740 & 5074 & 1.0 \\
GADA (RU) & 4.3 & 9.9 & 40.3 & 187 & 335 & 0.1 \\
IA-2A (RU) $^{\mathrm{a}}$ & 0.15 & 0.11 & 0.08 & 0.08 & 0.06 \\
\hline
\end{tabular}

a Normal values: ICA < 2.5 JDFU; IAA < 1.56 RU; GADA < 5.36 RU; IA-2A < 0.43 RU

${ }^{\mathrm{b}}$ Maternal sample taken 2 months after childbirth

Table 2. Kinetics of enterovirus antibodies in the maternal samples

\begin{tabular}{|c|c|c|c|c|c|c|c|}
\hline \multirow[t]{2}{*}{ Time } & \multicolumn{2}{|c|}{ 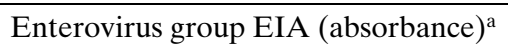 } & \multicolumn{5}{|c|}{ Neutralization titre $^{\mathrm{b}}$} \\
\hline & $1: 100$ & $1: 1000$ & EV-6 & CAV-9 & CBV-4 & HPEV-1 & All others ${ }^{\mathrm{c}}$ \\
\hline Pregnancy week 12 & 2.2 & 0.5 & $<4$ & 1024 & 256 & 16400 & $\leq 4$ \\
\hline Postnatal week 14 & 2.3 & 0.8 & 4 & 1024 & 256 & 16400 & $\leq 4$ \\
\hline
\end{tabular}

a Sera were diluted as indicated and assayed for IgG-class antibodies to a synthetic peptide representing the enteroviruscommon antigen

b Plaque-neutralization assay with $85 \%$ inhibition as the end point. The reciprocal of the corresponding serum dilution is

Enterovirus group-specific antibodies were slightly increased in maternal serum taken after delivery compared with the sample taken at the $12^{\text {th }}$ week of gestation (Table 2), implying that the mother had contracted an enterovirus infection during pregnancy. These antibodies were also found postnatally in the infant's serum and decreased at the rate expected thus indicating there was no putative chronic infection (data not shown). Virus-specific neutralization assays showed that the infection in the mother had been caused by echovirus 6 because the serotype-specific antibody titre increased from less than 4 to 16 during pregnancy (Table 2). The maternal serum also consistently contained a very high titre of antibodies against human parechovirus 1 (echovirus 22). Attempts to isolate cytopathogenic viruses and to find enteroviral RNA by reverse transcriptase polymerase chain reaction in the blood specimens were not successful.

At the age of 3 months, the infant's T cells proliferated normally in response to mitogen (PHA) stimulation $(\mathrm{SI}=32)$. Increased antigen-specific T-cell responses were found to bovine insulin $(\mathrm{SI}=3.1)$ and to purified enterovirus $(\mathrm{CVB}-4)$ particles $(\mathrm{SI}=4.2)$. At the age of 12 months, a positive T-cell proliferation response was seen only to the control antigen, tetanus toxoid.

\section{Discussion}

Several lines of evidence suggest that our patient's insulin-deficient diabetes was associated with a beta- given. Virus serotypes used: EV-6, echovirus 6; CAV-9, coxsackievirus A9, CBV-4, coxsackievirus B4, HPEV-1, human parechovirus 1 , formerly known as echovirus 22

${ }^{\mathrm{c}}$ Other enterovirus serotypes tested: coxsackieviruses B1, B2, B3, B5, B6

cell targeted autoimmune mechanism induced in utero. The strongest evidence is the presence of circulating antibodies against islet cells and their antigens, such as insulin and GAD. These autoantibodies have been shown to be strongly associated with Type I diabetes and IAA have been reported to often be the first antibodies to appear before the development of diabetes [10]. In our study the concentration of IAA was extraordinarily high, even in the sample taken on the day of birth before the initiation of insulin treatment. Concentrations of GADA levels increased soon after birth, indicating an active betacell targeted autoimmune process. The patient carried the HLA-DQB allele $* 0302$ which is often associated with the development of beta-cell autoimmunity and Type I diabetes. Furthermore, her T cells responded to stimulation with bovine insulin and coxsackievirus B4.

The serological studies showed that the mother had contracted an enteroviral infection possibly caused by echovirus 6 or other cross-reacting agent during pregnancy. It is possible but not proved by the data available that this maternal infection also spread to the fetus. As T-cell responses to enteroviruses are known to include reactions to cross-reactive epitopes in capsid protein [7], the putative fetal echovirus 6 infection might be responsible for the reactivity we observed to coxsackievirus B4 antigens. The Tcell response was clearly positive 3 months but no longer at 12 months after birth, supporting the diagnosis of an intrauterine infection. We have recently found that echovirus 6 effectively infects and kills cultured human beta-cells [11] and Roivainen et al., un- 
published results), making it possible that the virus could have directly infected the fetal pancreas.

Enteroviral infections have been reported to be temporally associated with the appearance of isletspecific autoantibodies [12]. Moreover, there is epidemiological evidence of an increased frequency of enteroviral infections during pregnancies from which children who later develop Type I diabetes are born [13]. We conclude that the development of an autoimmune type of diabetes and pancreatic hypoplasia in our patient is most likely explained by a maternally transmitted enteroviral infection involving the fetal pancreas early in gestation. It is not certain whether the infection directly damaged pancreatic cells during organogenesis but it did induce an aggressive betacell targeted autoimmune attack. This resulted in massive beta-cell loss and insulin deficiency during the first half of pregnancy, subsequent severe fetal growth retardation and immediate postnatal diabetes. A series of viruses, including rubella, mumps and coxsackievirus B3, have been shown to be capable of infecting human fetal islets and inducing functional changes in vitro $[14,15,16]$. Enteroviruses have also been found to cause islet cell damage in newborn infants with coxsackievirus encephalomyocarditis [17]. Our study shows that beta-cell autoimmunity can be induced even in utero. This ought to be acknowledged when planning strategies to prevent Type I diabetes.

Acknowledgements. These studies were supported in part by a Shared Cost Action of the Medical and Health Research of the European Community (contract No. BMH4-CT98-3952) on enterovirus-induced beta-cell damage.

\section{References}

1. Lindberg B, Ivarsson SA, Landin-Olsson M, Sundkvist G, Svanberg L, Lernmark A (1999) Islet autoantibodies in cord blood from children who developed Type I (insulindependent) diabetes mellitus before 15 years of age. Diabetologia 42: 181-187

2. Shield JP, Gardner RJ, Wadsworth EJ et al. (1997) Aetiopathology and genetic basis of neonatal diabetes. Arch Dis Child 76: F39-F42

3. Gardner RJ, Mungall AJ, Dunham I et al. (1999) Localisation of a gene for transient neonatal diabetes mellitus to an $18.72 \mathrm{Cr} 3000$ (approximately 5.4 Mb) interval on chromosome 6q. J Med Genet 36: 192-196
4. Stoffers DA, Zinkin NT, Stanojevic V, Clarke WL, Habener JF (1997) Pancreatic agenesis attributable to a single nucleotide deletion in the human IPF1 gene coding sequence. Nat Genet 15: 106-110

5. Kulmala P, Savola K, Petersen JS et al. (1998) Prediction of Insulin-Dependent Diabetes Mellitus in Siblings of Children With Diabetes - A Population Based Study. J Clin Invest 101: 327-336

6. Williams AJ, Bingley PJ, Bonifacio E, Palmer JP, Gale EA (1997) A novel micro-assay for insulin autoantibodies. J Autoimmun 10: 473-478

7. Cello J, Strannegard O, Svennerholm B (1996) A study of the cellular immune response to enteroviruses in humans: identification of cross-reactive T cell epitopes on the structural proteins of enteroviruses. J Gen Virol 77: 2097-2108

8. Hyöty H, Hiltunen M, Knip M et al. (1995) A prospective study of the role of Coxsackie B and other enterovirus infections in the pathogenesis of IDDM. Diabetes 44: 652-657

9. Roivainen M, Knip M, Hyöty H, Kulmala P, Hiltunen M, Vähäsalo P, Hovi T, Åkerblom H (1998) Several different enterovirus serotypes can be associated with prediabetic autoimmune episodes and onset of overt IDDM. J Med Virol 56: 74-78

10. Ziegler AG, Hummel M, Schenker M, Bonifacio E (1999) Autoantibody appearance and risk for development of childhood diabetes in offspring of parents with Type 1 diabetes: the 2-year analysis of the German Babydiab Study. Diabetes 48: 460-468

11. Roivainen, M, Rasilainen, S, Ylipaasto, P et al. (2000) Mechanisms of coxsackievirus-induced damage to human pancreatic B-cells. J Clin Endocrinol Metab 85: 432-440

12. Hiltunen M, Hyöty H, Knip M et al. (1997) Islet cell antibody seroconversion in children is temporally associated with enterovirus infections. J Infect Dis 175: 554-560

13. Dahlquist GG, Ivarsson S, Lindberg B, Forsgren M (1995) Maternal enteroviral infection during pregnancy as a risk factor for childhood IDDM: a population-based case-control study. Diabetes 44: 408-413

14. Numazaki K, Goldman H, Wong I, Wainberg MA (1989) Infection of cultured human fetal pancreatic islet cells by rubella virus. Am J Clin Pathol 91: 446-451

15. Parkkonen P, Höyty H, Koskinen L, Leinikki P (1992) Mumps virus infects beta cells in human fetal islet cell cultures upregulating the expression of HLA class I molecules. Diabetologia 35: 63-69

16. Vuorinen T, Nikolakaros G, Simell O, Hyypiä T, Vainionpää R (1992) Mumps and Coxsackie B3 virus infection of human fetal pancreatic islet-like cell clusters. Pancreas 7: 460-464

17. Ujevich MM, Jaffe R (1980) Pancreatic islet cell damage. Its occurrence in neonatal coxsackievirus encephalomyocarditis. Arch Pathol Lab Med 104: 438-441 